\title{
Effect of Weed Management Practices on Growth and Economics of Transplanted Rice under Sodic Soil
}

\author{
C. Nivetha*, G. Srinivasan and P.M. Shanmugam \\ Department of Agronomy, Anbil Dharmalingam Agricultural College and Research Institute, \\ Trichy, Tamil Nadu, India \\ *Corresponding author
}

\section{A B S T R A C T}

Field experiment was conducted at Anbil Dharmalingam Agricultural College and Research Institute, Tamil Nadu Agricultural University, Tiruchirapalli, Tamil Nadu during

\section{Keywords}

Weed density, Weed control efficiency, Weed index, Grain yield, Straw yield and Benefit Cost ratio.

\section{Article Info}

Accepted:

15 October 2017 Available Online: 10 December 2017 rabi 2016-2017 to evaluate the weed management practices in transplanted rice under sodic soil. The experiment consisted of 12 treatments laid out in Randomized Complete Block Design with three replications consisting of three pre-emergence herbicides integrated with post emergence herbicides and one hand weeding at 40 DAT, two early post emergence herbicides and one post emergence herbicide, hand weeding twice at 20 and 40 DAT, compared with weed free and unweeded check. The weed flora of the experimental site consisted of Cynodon dactylon, Echinochloa colona and Panicum repens in grasses, Cyperus rotundus and Cyperus difformis in sedges and Ammannia baccifera, Ipomoea aquatica and Marsilea quadrifolia in broad leaved weeds. Grasses were found to be predominant category followed by sedges and broad leaved weeds. The results revealed that pre emergence application of bensulfuron methyl + pretilachlor at $60+600 \mathrm{~g}$ a.i. ha ${ }^{-1}$ on 3 DAT followed by hand weeding on 40 DAT recorded significantly higher grain and straw yield (4987 kg ha-1 and $6841 \mathrm{~kg} \mathrm{ha}^{-1}$ ) which remained at par with weed free check (4798 and $6741 \mathrm{~kg} \mathrm{ha}^{-1}$ ). In terms of economics, highest net returns (Rs. $47765 \mathrm{ha}^{-1}$ ) and B: $\mathrm{C}$ ratio (2.49) was realized compared to that weed free check (Rs. 42640 ha $^{-1}$ ) and B: C ratio $(2.25)$.

\section{Introduction}

Rice is cultivated in a very wide range of ecosystems from irrigated to shallow lowlands, mid-deep lowlands and deep water to uplands. Transplanting is the major method of rice cultivation in India. Weeds are a major impediment to rice production through their ability to compete for resources and their impact on product quality. Out of losses due to various biotic stresses, weeds are known to account for nearly one third. Transplanted rice is particularly infested by heterogeneous types of weed flora under lowland ecosystem, which reduces yield up to 48 per cent with an annual loss of 15 million tonnes due to weed competition. Prevention of weed competition and provision of weed free environment at critical period of rice growth is necessary for successful rice production (Murali and Gowthami, 2017). Weed competition is one of the prime yield limiting constraints in rice resulting in yield reduction of 28-45 per cent (Maheshwari et al., 2015). Manual weeding although effective and most common practice of weed control in transplanted rice, raising 
cost of labour and their non-availability in time lead to the search for alternative methods. Herbicides offer the most effective, economical and practical way of weed management (Sureshkumar and Durairaj, 2016). So, there is a need to evaluate the effect of new herbicides on growth and economics of transplanted rice under sodic soil condition in order to gain profitability and for providing wider options to farmers.

\section{Materials and Methods}

An experiment was conducted at Anbil Dharmalingam Agricultural College and Research Institute, Tiruchirapalli during rabi 2016-2017. The soil of the experimental field was sandy clay loam in texture with $\mathrm{pH}$ of 8.8 .

The experiment was laid out in randomized complete block design with twelve treatments were $\mathrm{T}_{1^{-}}$pre emergence application of butachlor at $1.5 \mathrm{~kg}$ a.i. ha $^{-1}$ on 3 days after transplanting (DAT) followed by $(f b)$ hand weeding on $40 \mathrm{DAT}, \mathrm{T}_{2^{-}}$pre emergence application of pyrazosulfuron ethyl at $25 \mathrm{~g}$ a.i. $\mathrm{ha}^{-1}$ on 3 DAT $f b$ hand weeding on 40 DAT, $\mathrm{T}_{3^{-}}$pre emergence application of pyrazosulfuron ethyl at $25 \mathrm{~g}$ a.i. $\mathrm{ha}^{-1}$ on 3 DAT $f b$ early post emergence application of bispyribac sodium at $25 \mathrm{~g}$ a.i. ha $^{-1}$ on 8-12 DAT, $\mathrm{T}_{4-}$ pre emergence application of bensulfuron methyl + pretilachlor at $60+600$ g a.i. ha ${ }^{-1}$ on 3 DAT $f b$ hand weeding on 40 DAT, $\mathrm{T}_{5^{-}}$pre emergence application of bensulfuron methyl + pretilachlor at $60+600$ g a.i. $\mathrm{ha}^{-1}$ on 3 DAT $f b$ early post emergence application of bispyribac sodium at $25 \mathrm{~g}$ a.i. ha $^{-1}$ on 8-12 DAT, $\mathrm{T}_{6^{-}}$pre emergence application of pyrazosulfuron ethyl at $25 \mathrm{~g}$ a.i. ha $^{-1}$ on 3 DAT $f b$ post emergence application of 2,4-D sodium salt at $80 \mathrm{~g}$ a.i. ha ${ }^{-1}$ on 25-30 DAT, $\mathrm{T}_{7^{-}}$pre emergence application of bensulfuron methyl + pretilachlor at $60+600$ $\mathrm{g}$ a.i. $\mathrm{ha}^{-1}$ on 3 DAT $f b$ post emergence application of 2,4-D sodium salt at $80 \mathrm{~g}$ a.i. $\mathrm{ha}^{-1}$ on 25-30 DAT, $\mathrm{T}_{8}$ - early post emergence application of bispyribac sodium at $25 \mathrm{~g}$ a.i. $\mathrm{ha}^{-1}$ on 8-12 DAT $f b$ post emergence application of 2,4-D sodium salt at $80 \mathrm{~g}$ a.i. $\mathrm{ha}^{-1}$ on 25-30 DAT, $\mathrm{T}_{9}$ - early post emergence application of oxadiargyl at $80 \mathrm{~g}$ a.i. $\mathrm{ha}^{-1}$ on 8 12 DAT $f b$ post emergence application of 2,4$\mathrm{D}$ sodium salt at $80 \mathrm{~g}$ a.i. ha ${ }^{-1}$ on 25-30 DAT, $\mathrm{T}_{10^{-}}$hand weeding twice at $20 \mathrm{fb} 40 \mathrm{DAT}$, $\mathrm{T}_{11^{-}}$unweeded check, $\mathrm{T}_{12^{-}}$weed free check and replicated thrice.

The pre emergence herbicides were applied at 3 DAT as sand mix application and the early post emergence application were applied at 812 DAT and post emergence application were applied at 30 DAT through knap sack sprayer using a spray volume of $500 \mathrm{~L} \mathrm{ha}^{-1}$.

The data on weed density and dry weight were recorded at 20,40 and 60 DAT and were subjected to square root $\mathrm{x}+0.5$ transformation before statistical analysis to normalize their distribution.

The growth and yield attributes like number of productive tillers per square metre, number of filled grains per panicle, test weight were recorded at the time of harvesting and threshing were recorded at the time of maturity. Economics of different treatments was calculated taking into account of the prevailing market prices of inputs and output.

\section{Results and Discussion}

The weed flora consisted of Cynodon dactylon, Echinochloa colona and Panicum repens in grasses, Cyperus rotundus and Cyperus difformis in sedges and Ammannia baccifera, Ipomoea aquatica and Marsilea quadrifolia in broad leaved weeds. Grasses were found to be the predominant category followed by sedges and broad leaved weeds. 
Table.1 Effect of different weed management practices on weed density, weed dry weight and weed control efficiency of transplanted rice under sodic soil

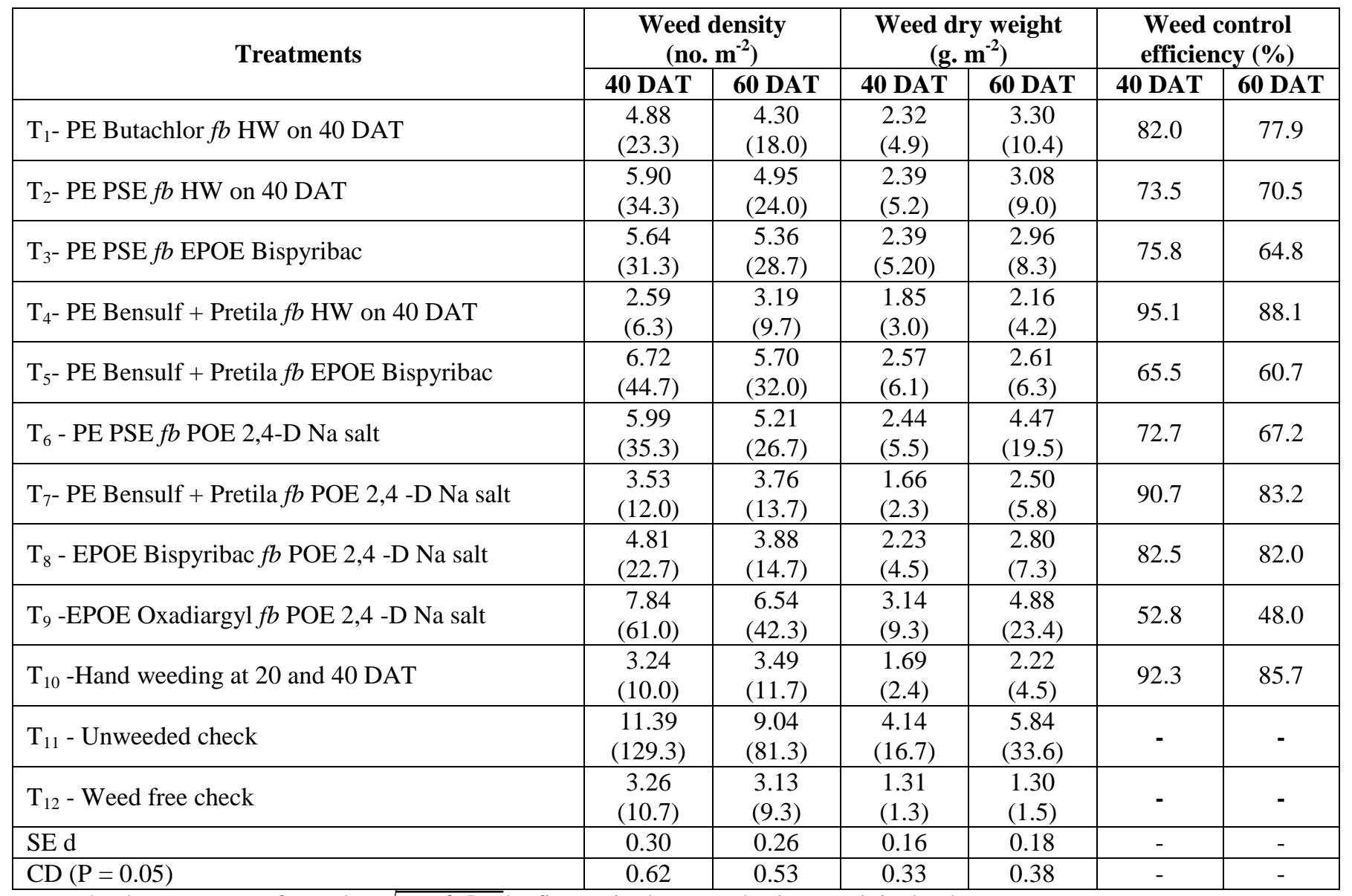

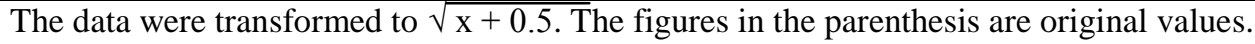

Table.2 Effect of different weed management practices on yield contributing characters of transplanted rice under sodic soil

\begin{tabular}{|c|c|c|c|}
\hline Treatments & $\begin{array}{l}\text { No. of productive } \\
\text { tillers }\left(\mathrm{m}^{-2}\right)\end{array}$ & $\begin{array}{c}\text { No. of grains } \\
\text { panicle }^{-1}\end{array}$ & $\begin{array}{c}\text { Grain yield } \\
\left(\mathrm{kg} \mathrm{ha}^{-1}\right)\end{array}$ \\
\hline $\mathrm{T}_{1}$ - PE Butachlor $f b \mathrm{HW}$ on $40 \mathrm{DAT}$ & 338 & 188 & 4215 \\
\hline $\mathrm{T}_{2}-\mathrm{PE}$ PSE $f b \mathrm{HW}$ on $40 \mathrm{DAT}$ & 294 & 157 & 4502 \\
\hline $\mathrm{T}_{3}$ - PE PSE $f b$ EPOE Bispyribac & 255 & 173 & 4299 \\
\hline $\mathrm{T}_{4}$ - PE Bensulf + Pretila $f b \mathrm{HW}$ on 40 DAT & 385 & 182 & 4987 \\
\hline $\mathrm{T}_{5^{-}}$PE Bensulf + Pretila $f b$ EPOE Bispyribac & 284 & 180 & 4199 \\
\hline $\mathrm{T}_{6}-\mathrm{PE}$ PSE $f b$ POE 2,4-D Na salt & 251 & 155 & 4088 \\
\hline $\mathrm{T}_{7}$ - PE Bensulf + Pretila $f b$ POE 2,4 -D Na salt & 342 & 163 & 4532 \\
\hline $\mathrm{T}_{8}$ - EPOE Bispyribac $f b$ POE 2,4 -D Na salt & 264 & 156 & 3435 \\
\hline $\mathrm{T}_{9}$-EPOE Oxadiargyl $f b$ POE 2,4 -D Na salt & 246 & 192 & 4046 \\
\hline $\mathrm{T}_{10}$-Hand weeding at 20 and $40 \mathrm{DAT}$ & 298 & 188 & 4405 \\
\hline $\mathrm{T}_{11}-$ Unweeded check & 239 & 112 & 2943 \\
\hline $\mathrm{T}_{12}-$ Weed free check & 330 & 158 & 4798 \\
\hline SE d & 25 & 10 & 209 \\
\hline $\mathrm{CD}(\mathrm{P}=0.05)$ & 53 & 22 & 433 \\
\hline
\end{tabular}


Table.3 Economics of weed management

\begin{tabular}{|c|c|c|c|c|}
\hline Treatments & $\begin{array}{c}\text { Total } \\
\text { variable } \\
\operatorname{cost}\left(₹ \text { ha }^{-1}\right)\end{array}$ & $\begin{array}{c}\text { Gross } \\
\text { return } \\
\left(₹ \text { ha }^{-1}\right)\end{array}$ & $\begin{array}{l}\text { Net return } \\
\left(₹ h^{-1}\right)\end{array}$ & $\begin{array}{l}\mathrm{B}: \mathrm{C} \\
\text { ratio }\end{array}$ \\
\hline $\mathrm{T}_{1}$ - PE Butachlor $f b \mathrm{HW}$ on $40 \mathrm{DAT}$ & 31219 & 67440 & 36221 & 2.16 \\
\hline $\mathrm{T}_{2}-\mathrm{PE}$ PSE $f b \mathrm{HW}$ on $40 \mathrm{DAT}$ & 32399 & 72032 & 39633 & 2.22 \\
\hline $\mathrm{T}_{3}-\mathrm{PE}$ PSE $f b$ EPOE Bispyribac & 34133 & 68784 & 34651 & 2.02 \\
\hline $\mathrm{T}_{4}-\mathrm{PE}$ Bensulf + Pretila $f b$ HW on 40 DAT & 32027 & 79792 & 47765 & 2.49 \\
\hline $\mathrm{T}_{5}$ - PE Bensulf + Pretilafb EPOE Bispyribac & 36048 & 67184 & 31136 & 1.86 \\
\hline $\mathrm{T}_{6}-\mathrm{PE}$ PSE $f b$ POE $2,4-\mathrm{D}$ Na salt & 31138 & 65408 & 34270 & 2.10 \\
\hline $\mathrm{T}_{7}$ - PE Bensulf + Pretila $f b$ POE 2,4 -D Na salt & 35088 & 72512 & 37424 & 2.07 \\
\hline $\mathrm{T}_{8}-\mathrm{EPOE}$ Bispyribac $f b$ POE 2,4 -D Na salt & 30418 & 54960 & 24542 & 1.81 \\
\hline $\mathrm{T}_{9}$-EPOE Oxadiargyl $f b$ POE 2,4 -D Na salt & 31048 & 64736 & 33688 & 2.09 \\
\hline $\mathrm{T}_{10}-$ Hand weeding at 20 and $40 \mathrm{DAT}$ & 36418 & 70480 & 34062 & 1.94 \\
\hline $\mathrm{T}_{11}-$ Unweeded check & 28803 & 47088 & 18285 & 1.63 \\
\hline $\mathrm{T}_{12}-$ Weed free check & 34128 & 76768 & 42640 & 2.25 \\
\hline
\end{tabular}

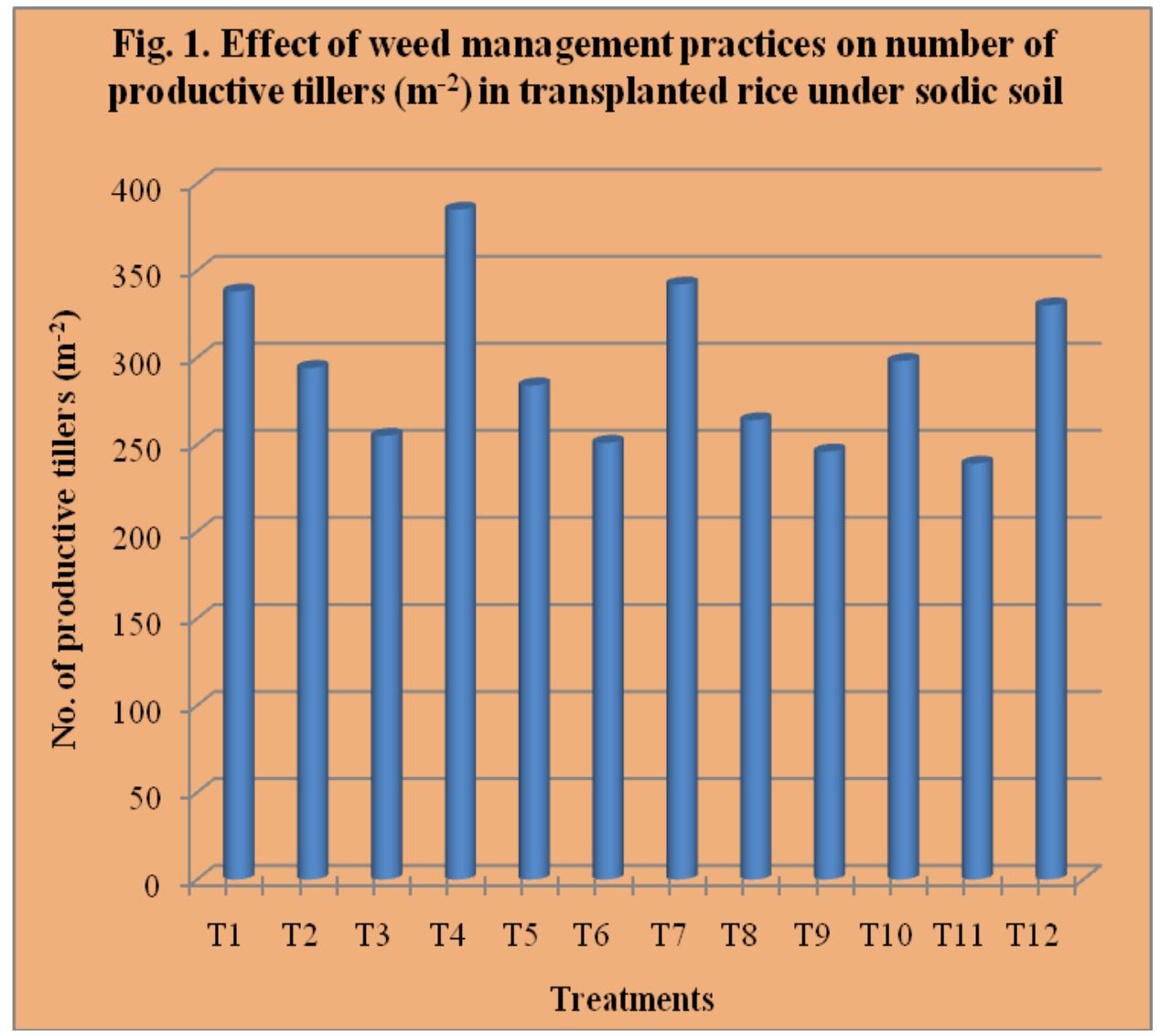




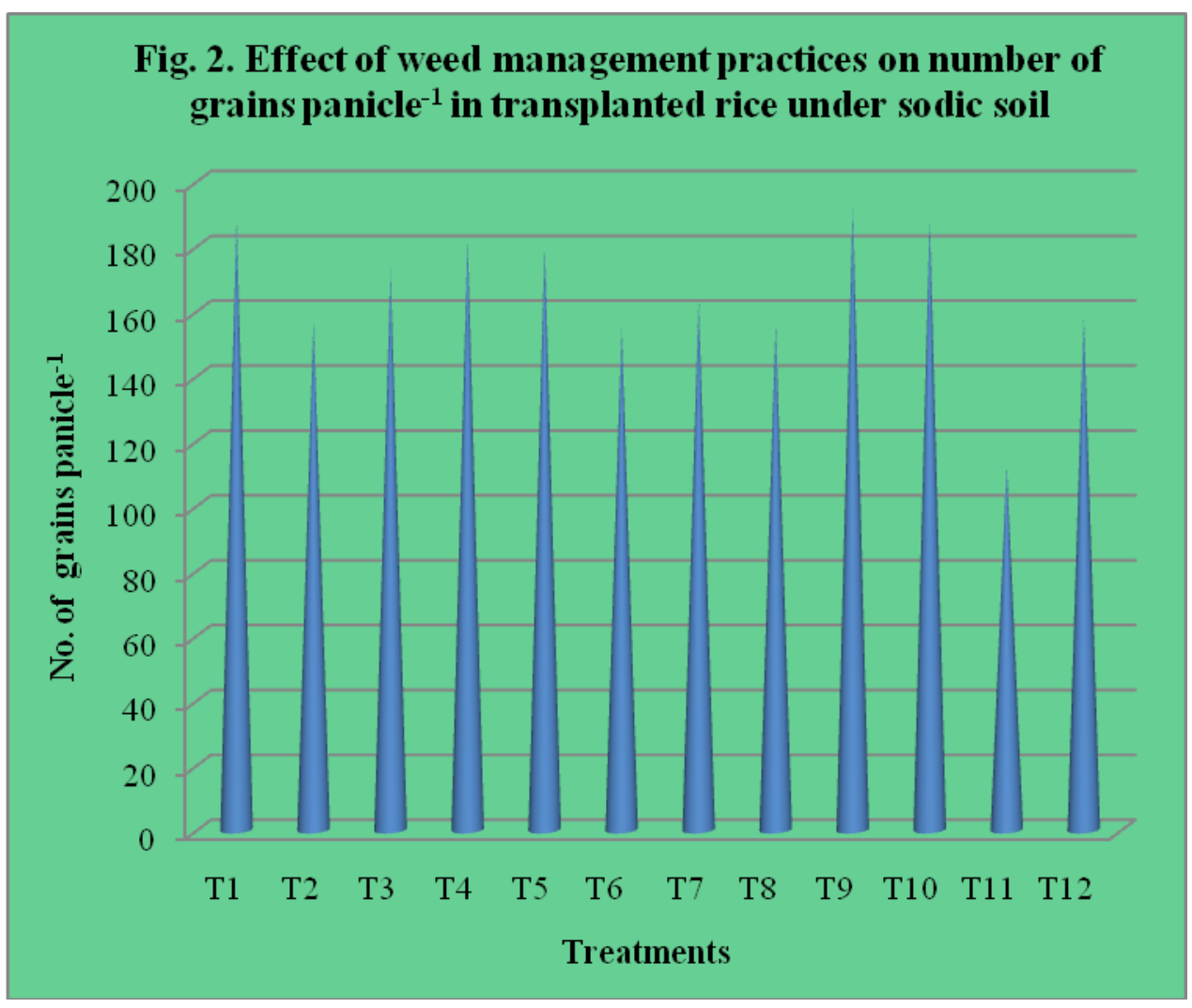

Fig. 3. Effect of weed management practices on grain yield $\left(\mathrm{Kg} \mathrm{ha}^{-1}\right)$ in transplanted rice under sodic soil

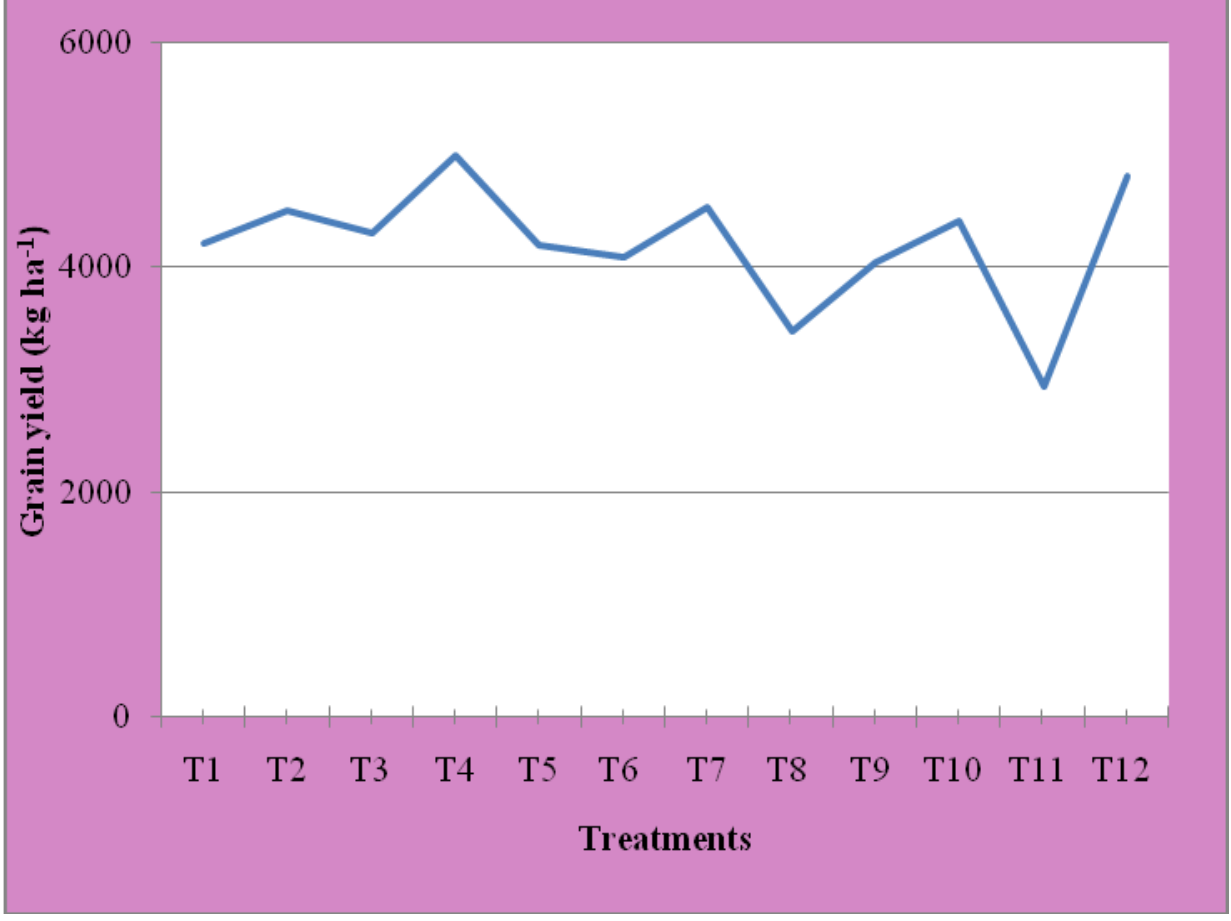




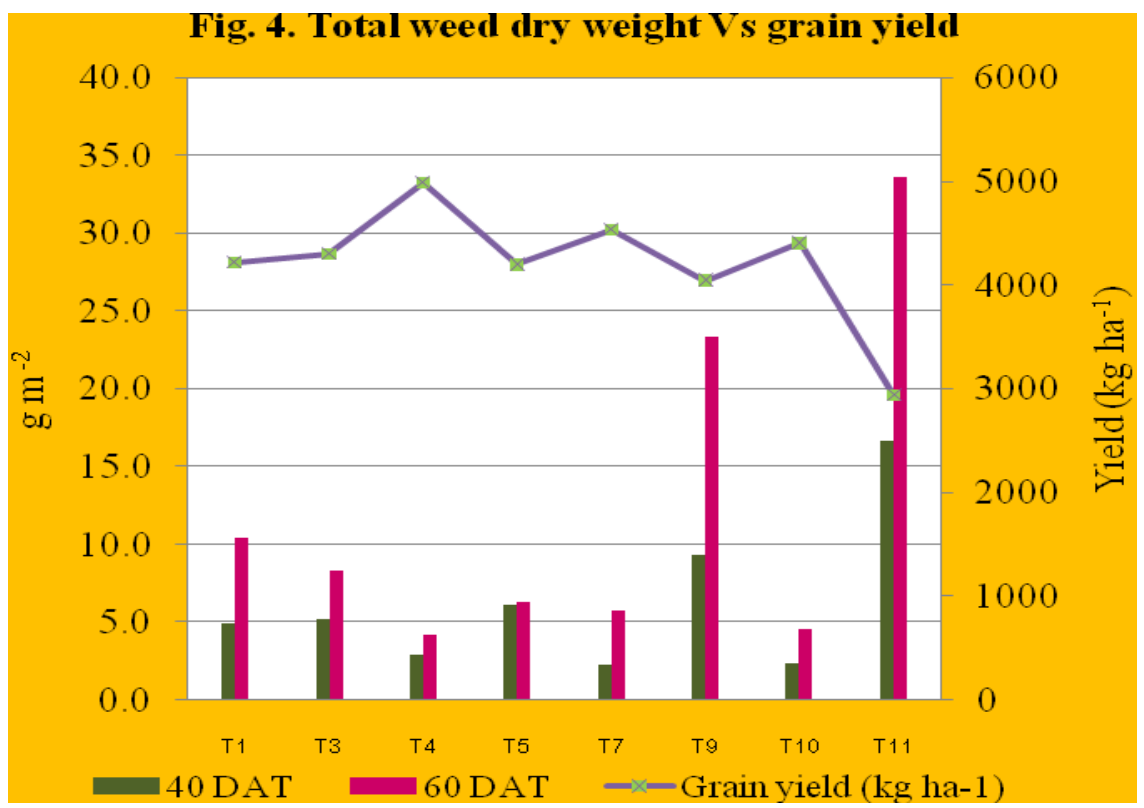

\section{Effect on weed dry weight}

The data presented in Table 1 on density and dry weight of weeds revealed that all the weed control treatments reduced the weed dry weight significantly from that of unweeded treatment. Among the weed control treatments, the lowest weed density and weed dry weight were registered in pre emergence application of bensulfuron methyl + pretilachlor at $60+600 \mathrm{~g}$ a.i. ha $^{-1}$ on 3 DAT $f b$ hand weeding on 40 DAT $\left(\mathrm{T}_{4}\right)$ at 40 and 60 DAT. It was comparable with weed free check $\left(\mathrm{T}_{12}\right)$. The highest weed density and dry weight recorded with unweeded check $\left(\mathrm{T}_{11}\right)$ for all the stages (Fig. 4). Higher weed control efficiency was registered with bensulfuron methyl + pretilachlor at $60+600 \mathrm{~g}$ a.i. $\mathrm{ha}^{-1}$ on 3 DAT $f b$ hand weeding on $40 \mathrm{DAT}\left(\mathrm{T}_{4}\right)$.

\section{Effect on yield}

A perusal of the data in Table 2, further revealed that among the herbicide treatments, number of productive tillers $\mathrm{m}^{-2}$ (385) (Fig. 1) and the highest grain yield (4987 $\mathrm{kg} \mathrm{ha}^{-1}$ ) were obtained with pre emergence application of bensulfuron methyl + pretilachlor at $60+600 \mathrm{~g}$ a.i. ha $^{-1}$ on 3 DAT $f b$ hand weeding on 40 DAT $\left(\mathrm{T}_{4}\right)$ and it was on par with weed free check $\left(\mathrm{T}_{12}\right)\left(4798 \mathrm{~kg} \mathrm{ha}^{-1}\right)$ with the weed control efficiency $(95.1 \%)$ on 40 DAT. The minimum grain yield and straw yield were observed in weedy check with a yield loss of $40.9 \%$ and $35.9 \%$, respectively as compared to $\mathrm{T}_{4}$ (Fig. 3). An increase in yield of $69.4 \%$ over weedy check was observed in case of $\mathrm{T}_{4}$. Abdhullah (2011), Uma et al., (2014) and Charan Teja (2015) also recorded the highest grain yield with bensulfuron methyl + pretilachlor. This was due to lesser weed competition and better uptake of nutrients by the crop. Yield attributes and grain yield was the lowest in unweeded check $\left(T_{11}\right)$. This might be due to interception of light by tall growing Echinochloa spp. resulting in poor phytosynthesis and photo-chemical energy supply which ultimately affected the translocation of photosynthates to the developing grains in rice (Murty and Murty, 1982). This has reflected in the lesser number of filled grains with lesser percentage in the unweeded check $\left(\mathrm{T}_{11}\right)$. Early post emergence application of oxadiargyl at $80 \mathrm{~g}$ a.i. ha $^{-1}$ on $8-12$ DAT $f b$ post emergence application of 2,4-D sodium salt $\left(\mathrm{T}_{9}\right)$ and pre emergence application of bensulfuron methyl + pretilachlor at $60+600 \mathrm{~g}$ a.i. $\mathrm{ha}^{-1}$ on 3 DAT $f b$ hand weeding on 40 DAT $\left(\mathrm{T}_{4}\right)$ registered more grains panicle $^{-1}$ (Fig. 2).

\section{Effect on economics}

The data in Table 3 indicated that hand weeding is expensive due to high labour cost but use of herbicides was cheaper in cost and effective in 
controlling the weeds and reducing total energy required for rice cultivation. Similar findings were reported by Srinivasan and Chaudhary (1993).

The highest gross returns (Rs. 89,597 ha ${ }^{-1}$ ) were observed with $\mathrm{T}_{11}$. While the lowest gross returns (Rs. 55,839ha ${ }^{-1}$ ) as observed with weedy check. The gross returns followed similar trend as that of grain yield. The highest benefit cost ratio (1.91) was observed with $T_{11}$ and was followed by $T_{10}$ which showed almost the same ratio. All herbicide treatments registered higher benefit cost ratio over weedy check which recorded markedly higher than that observed with hand weeding at 20 and 40 DAT (1.65). The highest benefit cost ratio (BCR) obtained by $\mathrm{T}_{11}$ might be due to higher grain yield in this treatment compared to other treatments. The lower BCR in hand weeding treatment was mainly because of higher labour cost involved in hand weeding. Therefore, the higher cost involved in manual weeding was not compensated by the additional grain yield obtained in hand weeding resulting in lower BCR (1.65).

From this study, it could be concluded that under transplanted rice in sodic soil, pre emergence application of bensulfuron methyl + pretilachlor at $60+600 \mathrm{~g}$ a.i. ha ${ }^{-1}$ on 3 DAT $f b$ hand weeding on 40 DAT $\left(\mathrm{T}_{4}\right)$ resulted in increased yield attributes and nutrient uptake by rice. This has reflected in increased grain and straw yield. The same treatment has shown broad spectrum of weed control, higher net return and BCR. This was followed by weed free check $\left(\mathrm{T}_{12}\right)$.

\section{References}

Abdhullah, Md. 2011. Bio-efficacy of bensulfuron methyl + Pretilachlor 6.6\% GR against weed suppression in transplanted rice. Bangladesh Journal. Weed Sci., 2 (1\&2): 913.

Charan Teja, K., B. Duary and M. K. Bhowmik. 2015. Efficacy of herbicides on weed management in wet season transplanted rice. Journal of Crop and Weed, 11: 224227.

Maheswari, M. D., A. S. Rao, P. Prasuna Rani and B. Venkateswarlu. 2015. Effect of Weed Management 5Practices on Growth and Economics of Transplanted Rice. International Journal of Pure and Applied Bioscience, 3(3): 113-116.

Murali, A. P. and S. Gowthami. 2017. Early Post Emergence Herbicide and Their Influence on Weed Population Dynamics in Transplanted Rice (Oryza Sativa L.). Chemical Science and Review Letter, 6(21): 561-566.

Murty, P. S. and K. S. Murty. 1982. Efficiency of $14 \mathrm{c}$ sucrose translocation in high and low sterile rice varieties under normal and low light conditions. Journal of Nuclear Agriculture and Biology, 11: 100-101.

Srinivasan, G. and G. K. Chaudhary. 1993. Energy requirement for controlling weeds in transplanted rice. Indian Journal of Agronomy. 38: 635-636.

Sureshkumar, R. and Durairaj. 2016. Weed characters and indices of transplanted rice as influenced by different weed management practices. International Journal of Agriculture Sciences. 8(51): 2221-2223.

Uma, G. and M. V. Ramana. 2014. Evaluation of low dose herbicides in transplanted rice (Oryza sativa L.). International Journal of Applied Biology and Pharmaceutical Technology, 5 (4): 96-101.

\section{How to cite this article:}

Nivetha, C., G. Srinivasan and Shanmugam, P.M. 2017. Effect of Weed Management Practices on Growth and Economics of Transplanted Rice under Sodic Soil. Int.J.Curr.Microbiol.App.Sci. 6(12): 1909-1915. doi: https://doi.org/10.20546/ijcmas.2017.612.217 